\title{
The effect of tonsillectomy on formant sound frequency
}

\author{
Bambang Udji Djoko Rianto*, Jenny Idris, Sagung Rai Indrasari \\ Otorhinolaryngology Head and Neck Surgery Department, Faculty of Medicine, Public \\ Health, and Nursing, Universitas Gadjah Mada, Yogyakarta
}

DOI: http://dx.doi.org/10.19106/JMedScie/005003201805

\section{ABSTRACT}

Vocal tract resonance characteristics are reflected by formant frequencies which are determined by the size and shape of the vocal tract. Tonsillectomy may cause changes in the structure of the oral cavity as a resonator in the speech process. The aim of this study was to evaluate the effect of tonsillectomy on formant sound frequency. This was a pretest and post-test only design study conducted in the Department of Otorhinolaryngology, Dr. Sardjito General Hospital, Yogyakarta between August and November 2012. The inclusion criteria were chronic tonsillitis; tonsil size was T3-T4, and age up to 45 years, whereas the exclusion criteria were craniofacial abnormality and neurological disorders. All patients performed a sound analysis by recording formant frequencies 1 (F1), F2 and $\mathrm{F} 3$ vowels /a/, /e/, /i/, /o/, and / $/ \mathrm{l} /$ at 1 day before and 4 weeks after surgery. Twenty $(60 \%)$ female patients and $16(40 \%)$ male patients were involved in this study. The T3-T3 tonsil size were $25(62.5 \%)$ samples and the lowest in T3-T4/T4-T3 were $6(15 \%)$ samples. Significantly increase of all F1 vowels (paired t-test $p<0.05)$ except for vowel /i/ $(p>0.05)$ was observed. However, no significantly change of F2 except for vowel /e/ and F3 except for vowel / $\mathrm{u} /$ were observed $(p>0.05)$. In conclusion, tonsillectomy generally affects $F 1$ but not affect F2 and F3.

\section{ABSTRAK}

Karakteristik resonansi traktus vokalis ditunjukkan oleh frekuensi formant yang ditentukan oleh ukuran dan bentuk traktus vokalis. Tonsilektomi dapat menyebabkan perubahan pada struktur rongga mulut yang berfungsi sebagai resonator proses bicara. Tujuan penelitian ini untuk menentukan pengaruh tonsilektomi terhadap frekuensi formant suara. Penelitian dengan rancangan pre-test and post-test only experimental ini dilakukan di Departemen Telinga Hidung Tenggorok-Kepala Leher, RSUP Dr. Sardjito, Yogyakarta periode bulan Agustus sampai November 2012. Kriteria inklusi adalah tonsilitis kronis; ukuran tonsil T3-T4 dan usia hingga 45 tahun. Kriteria eksklusi adalah kelainan kraniofasial dan gangguan neurologis. Seluruh pasien dianalisis suaranya dengan merekam frekuensi fromant 1 (F1), F2 dan F3 vokal /a/, /e/, /i/, /o/, dan /u/ pada 1 hari sebelum dan 4 minggu setelah tonsilektomi. Sebanyak $24(60 \%)$ subjek perempuan dan $16(40 \%)$ subjek laki-laki terlibat dalam penelitian. Ukuran tonsil T3-T3 terbanyak adalah $25(62,5 \%)$ subjek dan T3-T4/T4-T3 sebanyak 6 (15\%) subjek. Terjadi kenaikan bermakna semua vokal pada F1 (uji t pasangan $p<0.05)$ kecuali vocal $/ i /(p>0.05)$. Akan tetapi, tidak terjadi perubahan F2 kecuali vokal /e/ dan F3 kecuali vokal /u/ ( $p>0.05)$. Dapat disimpulkan, tonsilektomi secara umum mempengaruhi $F 1$ tetapi tidak terhadap F2 dan F3.

Keywords : tonsillectomy - formant frequency - sound analysis - adenoidectomy resonator structure

$\overline{{ }^{*} \text { corresponding author: djoriant@ugm.ac.id }}$ 


\section{INTRODUCTION}

Tonsillectomy with or without adenoidectomy is a common surgical procedure on children in Western countries. A study showed that on average adenotonsillectomy varies widely between countries. Adeno-tonsillectomy in Canada in 1998 reported 19 cases per 10,000 children and 19 cases per 10,000 adults, in Northern Ireland there were 118 cases per 10,000 children, in UK 65 cases per 10,000 children, in the Netherlands 115 cases per 10,000 children and in Finland 76 per 10,000 adults. ${ }^{1}$ Data from the National Center for Health Statistics show about 418,000 tonsillectomy with or without adenoidectomy were done in the United States in $1996 .{ }^{2}$

Although there are many advantages of tonsillectomy, but treating physicians also need to consider the complications from surgery such as sore throat, nausea and vomiting after surgery, delayed intake of food, bleeding and changes in voice and death although rare. $^{3}$ Tonsillectomy can cause changes in the structure in the mouth cavity that play a role as a resonator in the speech formation process. ${ }^{4}$ Changes in the resonator structure after tonsillectomy can cause changes in individual speech characteristics which can be viewed from the sound parameter analysis that include frequency formant, jitter, shimmer, harmonic noise ratio (HNR) ${ }^{5-7}$ voice turbulence index (VTI), soft phonation index (SPI), degree of voiceless (DUV), and degree of voice breaks (DVB). Sound analysis has begun to be used for assessing characteristic the changes of speech in patients who undergo surgery in the airway area especially tonsillectomy with varying results. ${ }^{6,7}$ Study to evaluate the change in the sound color (timbre) after surgery has not yet been extensively conducted in Indonesia.

Human voice characteristics is divided into two types: 1) non-acoustic characteristics, examples are pulses and time; and 2) acoustic characteristics, which are composed from pitch, formant and formant bandwidth. Pitch is formant to zero
(F0). Formant is defined as the spectrum of wave crest to wave crest in the human voice. Formant bandwidth is the width of a formant. When humans are speaking and pronouncing vowels they can produce more than four formants. To distinguish a sound vowel requires two formants, namely the first formant (F1), which corresponds to the position of the tongue against soft palate while talking and the second formant (F2), which is associated with position the tongue in front or behind while speaking. The third formant (F3), the fourth formant (F4) and so on, affect the sound (timbre) color. ${ }^{8}$

Based on the above reasoning it is necessary to do speech characteristic analysis before and after tonsillectomy with or without adenoidectomy objectively so that it can be used as a basis to explain about the change of speech characteristics based on the parameters of sound analysis after tonsillectomy. This study determined the effect of tonsillectomy to the vocal tract using sound analysis parameters that include the formant frequency (F1, F2 and F3).

\section{MATERIALS AND METHODS}

\section{Study design}

This research used a pretest and posttest only experimental design (before and after). The data were collected from the measurements of the sound analysis using PRAAT 5.1.05 software on 1 day before and 4 weeks after tonsillectomy with or without adenoidectomy. PRAAT is a computer program for analyzing, synthesizing, and manipulating speech. PRAAT 5.1.05 software is currently the most accepted, standardized and popular for speech analysis. It is particularly helpful in phonetics classes and academic sessions for making spectrogram, pitch tracks and similar functions. Whatever be the level of knowledge about speech analysis and phonetics, this tool can be easily used to achieve desired results. Analyzing speech with PRAAT allows us to record a sound with a microphone or any other audio input device, or to read a sound from a sound file on disk. It will then be able 
to have a look 'inside' this sound. The upper half of the sound window will show a visible representation of the sound (the wave form). The lower half will show several acoustic analyses: the spectrogram (a representation of the amount of high and low frequencies available in the signal) is painted in shades of grey; the pitch contour (the frequency of periodicity) is drawn as a cyan curve; and formant contours (the main constituents of the spectrogram) are plotted as red dots. PRAAT is most often used with speech sounds, in which case the pitch contour is associated with the vibration of the vocal folds and the formant contours are associated with resonances in the vocal tract. ${ }^{9}$

\section{Time and location}

This research was conducted in the Ear Nose and Throat Department of Dr. Sardjito General Hospital Yogyakarta, Dr. Soeradji Tirtonegoro Hospital Klaten-Central Java and Saras Husada Hospital PurworejoCentral Java between August and November 2012.

\section{Population and samples}

The study population was patients who underwent tonsillectomy with or without adenoidectomy. The inclusion criteria were: 1) chronic tonsillitis patients with or without adenoid hypertrophy (Mallampati class IIIII), 2) tonsil size greater than or equal to $\mathrm{T} 3,3$ ) in the past 1 week did not experience cough and cold, 4) normal mandibular and neck anatomy structures 5) method of tonsillectomy with Guillotine or dissection, 6) age equal to or more than 5 years, and 7) willing to follow the research and sign the informed consent or proxy consent form. The exclusion criteria in this study were craniofacial abnormalities and neurological disorders.

This study was approved by the Medical and Health Research Ethics Committee,
Faculty of Medicine, Universitas Gadjah Mada, Yogyakarta (Ref. KE/FK/775/EC). All patients performed a standard sound analysis by recording vowel /a/, /e/, /i/, /o/, and $/ \mathrm{u} /$ (Boersma, and van Heuven) in 1 day before and 4 weeks after surgery using PRAAT 1.5.05 software. ${ }^{9}$ Based on the sample size calculation for different mean of variables: F1, F2, F3 before and after surgery, the number of sample size used in this study was 36 plus estimated drop out $10 \%$, which were 40 samples.

\section{Statistical analysis}

Data were presented as mean \pm standard deviation (SD) or percentage. The difference of the formant frequency (F1, F2, and F3) before and after tonsillectomy was analyzed using paired t-test with $\mathrm{p}$ value $<0.05$ as considered significant.

\section{RESULTS}

The characteristics of subjects by group age, sex, BMI (body mass index), tonsil size, type of operation, and method of operation are presented in TABLE 1. From the all subjects, $24(60 \%)$ subjects were female and $16(40 \%)$ samples were male. Based on the age distribution, it was divided into two groups, age $5-<18$ years old were 32 $(80 \%)$ samples and $\geq 18$ years old were 8 $(20 \%)$ samples. The youngest age was 5 years old and the oldest was 42 years old. Based on the distribution of BMI, obtained the largest frequency on underweight group of $19(47.5 \%)$ sujects and fewest frequencies in the overweight group of $6(6 \%)$ samples. Most tonsil size is T3-T3 which is $25(62,5 \%)$ samples and lowest is T3-T4 / T4-T3 as many as $6(15 \%)$ samples. Based on the type of operation, total tonsillectomy in all samples were $40(100 \%)$ samples. There were 18 (45\%) samples with Guillotine method and $22(55 \%)$ samples with dissection method. 
TABLE 1. Characteristics of research subjects

\begin{tabular}{|c|c|}
\hline Variable & $\mathrm{n}(\%)$ \\
\hline \multicolumn{2}{|l|}{ Gender } \\
\hline - Female & $24(60)$ \\
\hline - Male & $16(40)$ \\
\hline \multicolumn{2}{|l|}{ Age (years) } \\
\hline - $5-18$ & $32(80)$ \\
\hline$\cdot \geq 18$ & $8(20)$ \\
\hline \multicolumn{2}{|l|}{ BMI (body mass index) } \\
\hline - Underweight & $19(47.5)$ \\
\hline - Normal & $15(37.5)$ \\
\hline - Overweight & $6(15.0)$ \\
\hline \multicolumn{2}{|l|}{ Palatine tonsil size } \\
\hline • $\mathrm{T} 3-\mathrm{T} 3$ & $25(62.5)$ \\
\hline - $\mathrm{T} 3-\mathrm{T} 4 / \mathrm{T} 4-\mathrm{T} 3$ & $6(15.0)$ \\
\hline - $\mathrm{T} 4-\mathrm{T} 4$ & $9(22.5)$ \\
\hline \multicolumn{2}{|l|}{ Surgery type } \\
\hline - Tonsillectomy & $40(100)$ \\
\hline - Adeno-tonsillectomy & $0(0)$ \\
\hline \multicolumn{2}{|l|}{ Surgery method } \\
\hline - Guillotine & $18(45)$ \\
\hline - Dissection & $22(55)$ \\
\hline
\end{tabular}

An average change of F1, F2, and F3 before and after surgery in all vowels was observed in this study (TABLE 2). An increase in mean $\mathrm{F} 1$ for all vowels, F2 /e/ \& /i/, and F3 for almost all vowels except /a/. Significant mean increases occurred in almost all $F 1$ vocals $(\mathrm{p}<0.05)$ except $/ \mathrm{i} /(\mathrm{p}>0.05)$. This difference was probably because in making the vowel /i/, the highest position of the tongue was in front and did not require sticking the tongue on the pharynx wall so that on the enlargement of the tonsils and after tonsillectomy did not affect F1.

TABLE 2. Average difference of F1, F2, and F3 before and after tonsillectomy on vowels

\begin{tabular}{|c|c|c|c|c|c|c|c|c|}
\hline Vowel & Operation & $\mathrm{n}$ & $\begin{array}{c}\mathrm{F} 1 \\
(\mathrm{Mean} \pm \mathrm{SD})\end{array}$ & $\mathrm{p}$ & $\begin{array}{c}\mathrm{F} 2 \\
(\mathrm{Mean} \pm \mathrm{SD})\end{array}$ & $\mathrm{p}$ & $\begin{array}{c}\mathrm{F} 3 \\
(\text { Mean } \pm \mathrm{SD})\end{array}$ & $\mathrm{p}$ \\
\hline \multirow{2}{*}{ /a/ } & Pre-op & 40 & $882 \pm 177$ & \multirow{2}{*}{0.007} & $1537 \pm 167$ & \multirow{2}{*}{0.956} & $2756 \pm 392$ & \multirow{2}{*}{$0.056^{*}$} \\
\hline & Post-op & 40 & $965 \pm 142$ & & $1535 \pm 186$ & & $2653 \pm 490$ & \\
\hline \multirow{2}{*}{ /e/ } & Pre-op & 40 & $588 \pm 114$ & \multirow{2}{*}{0.008} & $2093 \pm 299$ & \multirow{2}{*}{$0.009^{*}$} & $2904 \pm 268$ & \multirow{2}{*}{0.360} \\
\hline & Post-op & 40 & $629 \pm 114$ & & $2142 \pm 409$ & & $2948 \pm 244$ & \\
\hline \multirow{2}{*}{ /i/ } & Pre-op & 40 & $502 \pm 99$ & \multirow{2}{*}{$0.382^{*}$} & $2362 \pm 285$ & \multirow{2}{*}{0.057} & $3166 \pm 218$ & \multirow{2}{*}{0.090} \\
\hline & Post-op & 40 & $514 \pm 112$ & & $2461 \pm 327$ & & $3232 \pm 231$ & \\
\hline \multirow{2}{*}{ /o/ } & Pre-op & 40 & $602 \pm 103$ & \multirow{2}{*}{0.018} & $1148 \pm 188$ & \multirow{2}{*}{$0.989^{*}$} & $2896 \pm 378$ & \multirow{2}{*}{$0.192 *$} \\
\hline & Post-op & 40 & $631 \pm 126$ & & $1137 \pm 249$ & & $2971 \pm 401$ & \\
\hline \multirow{2}{*}{$/ \mathrm{u} /$} & Pre-op & 40 & $533 \pm 79$ & \multirow{2}{*}{0.035} & $1132 \pm 244$ & \multirow{2}{*}{$0.638^{*}$} & $2940 \pm 278$ & \multirow{2}{*}{$0.035^{*}$} \\
\hline & Post-op & 40 & $557 \pm 95$ & & $1101 \pm 284$ & & $3043 \pm 288$ & \\
\hline
\end{tabular}

Note: Pre-op = before operation; Post-op= after operation; $\mathrm{n}=$ number of samples, $\mathrm{SD}=$ standard deviation; $\mathrm{p}=\mathrm{p}$ value; *

$=$ Wilcoxon test.

\section{DISCUSSION}

The significantly increases on $\mathrm{F} 1$ for letter $/ \mathrm{a} /, \mathrm{e} /, \mathrm{o} / \mathrm{and} / \mathrm{u} / \mathrm{,}$ in $\mathrm{F} 2$ for $/ \mathrm{e} /$ and $\mathrm{F} 3$ for $/ \mathrm{u} /$ after tonsillectomy were observed in this study $(\mathrm{p}<0.05)$ (TABLE 2$)$. Furthermore, no significantly different on $F 1, F 2$ and $F 3$ for all vowels between female and male before and after tonsillectomy was observed $(\mathrm{p}>0.05)$.

The studies of the effect of tonsillectomy on formant sound frequency have been reported by some authors with different results. Heffernan \& Raffety ${ }^{10}$ reported that the increase on $\mathrm{F} 1$ for $/ \mathrm{a} /$ and the decrease in F2 and F3 after tonsillectomy was observed. Furthermore, changes of F3 
and the third formant bandwidth (B3) for vowel $/ \mathrm{o} /$ and $/ \mathrm{a} /$, a slight decrease in the first formant bandwidth (B1), formant the second bandwidth (B2) for the vowel /a/, along with a mild decrease in the NHR which means diminished nasalized vowels, and the glottal consonants $/ \mathrm{h} /$ on patients after tonsillectomy were reporte. ${ }^{4}$ Whereas another study reported that F0, F1, F2 and F3 unchanged in females patients after tonsillectomy but F1 and F2 significantly changed in males patients. ${ }^{5}$ A preliminary study on sound acoustic changes after upper airway surgery in OSAS patients showed no F0 change, while F1 for vocal /a/ and F2 for vocal/e/ were significantly higher, and F1 for vowel /i/ and F2 for vowels /o/ and /u/ were significantly lower than before surgery. ${ }^{11}$

The effects of adeno-tonsillectomy on the spectrum speech in children aged 4-14 years old has been studied and the results showed that F0, jitter, shimmer, NHR, VTI, SPI, DUV, and DVB 1 month after surgery significantly decreased. In addition, there were significant differences of NHR, VTI, and DVB after surgery, which was close to the value at healthy group. ${ }^{6}$ The mirror-fogging test showed a decrease in hyper-nasality from an average of 3.2 before operation to 0 after surgery, while the Gutzman test showed the value of 1 before and 0 after the operation, and the average nasality severity index changed from 3.7 before surgery to 0.6 after surgery. ${ }^{12}$

The impact of tonsillectomy with or without adenoidectomy on speech and voice has been studied on children aged 4-12 years olds. A significant decrease in F0, Jitt, Shim, NHR, VTI, SPI, DUV, DVB, and peak amplitude variation (vAm) in the children underwent adenotonsillectomy was reported one month after surgery indicating the improvements of the speech and voice quality. ${ }^{6}$ Furthermore, the effect adenotonsillectomy on the speech spectrum in children aged between 5 and 14 years old, with enlarged palatine tonsils and hypetrophic adenoids has been also reported. ${ }^{7}$ An improvement in all the parameters include Fo, Jitt, Shim, NHR, VTI, SPI, DUV and
DVB after adenotonsillectomy was observed. In addition a postoperative normalization of NHR, VI and DVB compared with healthy children were also reported.

The mechanism of human speech production (vocal organ) is divided into 3 parts i.e. lung, vocal cord and vocal tract. ${ }^{13,14}$ Included in the vocal tract are larynx, pharynx, oral cavity and nasal cavity. The vocal organs include: 1) blowing: lungs, 2) air ducts: trachea, 3) ballot box: larynx 4) resonator: pharynx, mouth and nose..$^{15,16}$ The speech formation mechanism consists of 4 processes namely: 1) processing language; the content of the greeting is changed to symbols phonemically in the brain of the language center, 2) the generation of motor commands for vocal organs in the brain of the motor center, 3) articulatory movements by vocal organs under motor command, and 4) air emissions from the lungs in shaping speech. ${ }^{17}$

The speech process is initiated by the stimulating activity of the central nervous system to respiratory tract and vocal tract. Speech is a complex acoustic signal where information is sent to the brain at such high speed with 3-4 syllables per second that are spoken during a conversation. The phoneme is a discrete perception unit composed of complex sound elements that are encoded into neural release patterns in the lower hearing center of the brain for decoding at the higher hearing center. ${ }^{18}$

The sound source comes from the air in the lungs that is the result of inhalation and will be passed on larynx under control of the respiratory muscles, thus causing the vocal cord vibration. ${ }^{14,18,19}$ This mechanism produces periodic wave complexes known as glottal flows or voice sources in the form of a hum. The vocal cord vibration in female ranges from 200-300 per second, while in men about 100 per second and in children higher at 400 per second so the sound in male sounds heavier. Good muscular coordination and flow rate according to the subglottal pressure for certain articulation movements is very important to produce a normal amplitude speech pattern. ${ }^{14}$ 
Frequency of glottal or vocal cord is called frequency fundamental (F0) or otherwise known as pitch. ${ }^{13,19}$ The F0 on average at talk time is $120 \mathrm{~Hz}$ in males, 250 $\mathrm{Hz}$ in females and $400 \mathrm{~Hz}$ on children. ${ }^{14}$ There is another term used called frequency. The fundamental speech moment is $100 \mathrm{~Hz}$ in males and $200 \mathrm{~Hz}$ on female, with about 40 harmonization (formant frequency) of fundamental frequency represented in the form of a wave and transmitted to the vocal tract through vibration thus forming speech sounds. ${ }^{19}$ The vocal tract (sound resonator) functions as a multi resonant filter (influenced by the articulator movement) for the transmission of the sound wave with its particular shape and spectrum derived from the larynx, so that the hum sounds into a speech or an output sound of a vowel or sound meaningful consonants. ${ }^{14,18}$

In this study almost all $\mathrm{F} 1$ average for all vowels except $/ \mathrm{a} / \& / \mathrm{u} /$ before tonsillectomy had a significant difference in the age group $5-<18$ years and the age group $\geq 18$ years (TABLE 2). The total mean of F1 for all vowels after tonsillectomy was significantly different in the age group $5-<18$ years and the age group $\geq 18$ years. The average F2 and F3 for all vowels before and after the tonsillectomy was not significantly different in the age group of $5-<18$ years and age group $\geq 18$ years except the mean $\mathrm{F} 2 / \mathrm{o} /$ after tonsillectomy with $(\mathrm{p}<0.05)$. In the mean delta of F1, F2, and F3 were not significantly different in the $5-<18$ years age group and in the age group $\geq 18$ years.

No significantly difference before and after operation in F1, F2, \& F3 mean delta in all vowels on the Guillotine method and dissection was observed except F1/i/ ( $p$ $<0.05)$. There is no prior research comparing Guillotine and dissection methods. The average change before and after the operation and the mean delta of F1, F2, and F3 in each of the vowels /a/, /e/, /i/, /o/, and $/ \mathrm{u} /$ based on the operation type as variables are not typically discussed. In this research there were no research samples undergoing adenoidectomy and surgery (TABLE 2)

All subjects of the study were patients undergoing tonsillectomy. There are significant differences in mean scores before and after tonsillectomy based on the tonsil size distribution for $\mathrm{F} 1 / \mathrm{a} /, \mathrm{e} /, \& / \mathrm{o} /$ and the mean delta for $\mathrm{F} 1 / \mathrm{a} /$ and /i/. In F1 /i/ and $/ \mathrm{u} /$ and F2, F3 for all vowels there was no difference in total mean and mean delta. TABLE 2 showed that there are significant differences in total mean before and after tonsillectomy based on the BMI distribution for $\mathrm{F} 1$ in all vowels except /e/ before tonsillectomy, F2 /a/ before tonsillectomy, and $\mathrm{F} 2 / \mathrm{o} /$ and $/ \mathrm{u} /$ after tonsillectomy.

\section{CONCLUSION}

In conclusion, tonsillectomy generally affects F1 but not affect F2 and F3. It is recommended that patients who will undergo tonsillectomy need to be educated regarding the potential change of the F1. Further study is needed with longer sound evaluation time after tonsillectomy to evaluate whether the effect of tonsillectomy on F1 is temporary or permanent.

\section{ACKNOWLEDGEMENTS}

Authors would like to thanks the patients and parents who have participated in this study and Directors of Dr. Soeradji Tirtonegoro General Hospital, Klaten, Director of Saras Husada General Hospital, Purworejo, Central Java, Director of Dr. Sardjito General Hospital for their permission to perform this study. We would also like to thank all research assistants for their valuable assistances during the study.

\section{REFERENCES}

1. Van Den Akker, EH, Hoes, AW, Burton, MJ, Schilder, AG. Large international differences in (adeno) tonsillectomy rates. Clin Otolaryngol Allied Sci 2004; 29(2):161-4.

http://dx.doi.org/10.1111/j.0307-7772.2004.00771.x

2. Nelson ME, Gernon TJ, Taylor JC, McHugh JB, Thorne MC. Pathologic evaluation of routine pediatric 
tonsillectomy specimens: analysis of cost effectiveness. Otolaryngol Head Neck Surg 2010; 144(5):778-83. http://dx.doi.org/10.1177/0194599810393875

3. Baugh RF, Archer SM, Mitchell RB, Rosenfeld RM, Amin R, Burns JJ, et al. Clinical practice guideline: tonsillectomy in children. Otolaryngol Head Neck Surg 2010; 144 (1S): S1-30. https://doi.org/10.1177/0194599810389949

4. Ilk HG, Erogul O, Satar B, Ozkaptan Y. Effects of tonsillectomy on speech spectrum. J Voice 2002; 16(4):580-6. http://dx.doi.org/10.1016/S0892-1997(02)00133-9

5. Kandogan $\mathrm{T} \&$ Ozuer MZ. Effect of tonsillectomy on acoustic parameters. KBB-Forum 2006; 5(4): 141-4.

6. Salami A, Jankowska B, Dellepiane M, Crippa B, Mora R. The impact of tonsillectomy with or without adenoidectomy on speech and voice. Inter J Pediatr Otorhinolaryngol 2008; 72: 1377-84.

http://dx.doi.org/10.1016/j.ijporl.2008.05.019

7. Mora R, Crippa B, Dellepiane M, Jankowska B. Effects of tonsillectomy on speech spectrum in children. Inter $\mathbf{J}$ Ped Otorhinolaryngol 2007; 71: 1299304.

http://dx.doi.org/10.1016/j.ijporl.2007.05.005

8. Chládková K, Hamann S, Williams D, Hellmuth S. F2 slope as a Perceptual Cue for the Front-Back Contrast in Standard Southern British English. Lang Speech 2017; 60(3): 377-98. http://dx.doi.org/10.1177/0023830916650991

9. Boersma P and van Heuven V. Speak and unspeak with PRAAT. Glot Int 2001; 5(9/10): 341-7.

10. Haffernan CB and Rafferty MA. Effect of tonsillectomy on the adult voice. $\mathrm{J}$ Voice 2011; 25(4): e207-e10. http://dx.doi.org/10.1016/j.jvoice.2010.05.006

11. Bertino G, Matti E, Migliazzi S, Pagella $\mathrm{F}$, Tinelli C, Benazzo M. Acoustic changes in voice after surgery for snoring: preeliminary results. Acta Otorhinolaryngol Ital 2006; 26:110-14.

12. Aboloyoun AI, Ghorab S, Farooq MU. Palatal lifting prosthesis and velopharyngeal insufficiency: preliminary report. Acta Med Acad 2013; 42(1):55-60.

http://dx.doi.org/10.5644/ama2006-124.71

13. Pulakka H. Analysis of human voice production using inverse filtering, highspeed imaging, and electroglottography. [Thesis]. Helsinki: Helsinki University of Technology, 2005.

14. Warren RM. Speech. In: Warren RM editor. Auditory perception: an analysis and synthesis, $3^{\text {rd }}$ ed. New York: Cambride University Press, 2008: 174215.

http://dx.doi.org/10.1017/CBO9780511754777

15. Karjalainen M.

Kommunikaatioakustiikka. Otomedia Oy; 2000.

16. Behnke E. The mechanism of the human voice $15^{\text {th }}$ ed. London: J Curwen \& Sons LTD, 2010.

17. Honda M. Human speech production mechanisms. NTT Tech Rev 2003; 1(2):24-9.

18. Clark G. Speech (sound) processing. In: Clark $G$ ed. Cochlear implants: fundamentals and application. New York: Springer-Verlag 2003; 381-442. http://dx.doi.org/10.1007/0-387-21550-6 7

19. Gelfand SA. Speech perception. In: Gelfan SA ed. Hearing: an introduction to psychological and physiological acoustics $4^{\text {th }}$ ed. New York: CRC Press, 2005: 487-517. 